\title{
Transatlantica
}

Revue d'études américaines. American Studies Journal

\section{Years after Stonewall: The Legacies and Memory-making of the 1969 Riots}

Conference report on the "Stonewall at 50 and Beyond: Interrogating the Legacy and Memory of the 1969 Riots" symposium, Paris-Est Créteil

University, June 3-5, 2019

Michael Stambolis-Ruhstorfer

\section{(2) OpenEdition}

1 Journals

\section{Electronic version}

URL: https://journals.openedition.org/transatlantica/14493

DOI: 10.4000/transatlantica.14493

ISSN: 1765-2766

\section{Publisher}

Association française d'Etudes Américaines (AFEA)

\section{Electronic reference}

Michael Stambolis-Ruhstorfer, "50 Years after Stonewall: The Legacies and Memory-making of the 1969 Riots", Transatlantica [Online], 1 | 2019, Online since 01 July 2020, connection on 02 February 2023. URL: http://journals.openedition.org/transatlantica/14493 ; DOI: https://doi.org/10.4000/ transatlantica. 14493

This text was automatically generated on 2 February 2023.

Creative Commons - Attribution-NonCommercial-NoDerivatives 4.0 International - CC BY-NC-ND 4.0 https://creativecommons.org/licenses/by-nc-nd/4.0/ 


\section{Years after Stonewall: The Legacies and Memory-making of the 1969 Riots}

Conference report on the "Stonewall at 50 and Beyond: Interrogating the Legacy and Memory of the 1969 Riots" symposium, Paris-Est Créteil

University, June 3-5, 2019

Michael Stambolis-Ruhstorfer

\section{AUTHOR'S NOTE}

Link to the program: https://stonewallat50.sciencesconf.org

IMAGER (Institut des Mondes Anglophone, Germanique et Roman, UR 3958, Université Paris-Est Créteil)

IRISSO (Institut de Recherche Interdisciplinaire en Sciences Sociales, UMR 7170, Université Paris-Dauphine)

IRIS (Institut de Recherches Interdisciplinaires sur les enjeux Sociaux, UMR 8156 - U

997, EHESS, INSERM, Université Paris Nord)

\section{Deconstructing Stonewall in France}

1 What is "Stonewall"? A small bar in Manhattan. An historical event marked by rioting and police violence. A metonym for the radical turn in queer liberation. A romanticized, white-washed discourse riding the channels of US imperialism, erasing and reconfiguring local mobilization histories in its path. A mythical rereading of the past that reflects the social and political power of the people who created it.

2 It is, undoubtedly, all of these things and much more. Yet beyond the content of the many responses, it is asking the question itself and inviting people to the table to answer it that also requires unpacking. Indeed, as the story of this conference held in 
Créteil in June 2019 shows, asking questions about Stonewall is a delicate task with high stakes. It is not enough to examine which groups of people continue to benefit from and augment the seemingly ever-growing aura of the "Stonewall Myth," as Armstrong and Crage (2006) have called it. Rather, in the year of the $50^{\text {th }}$ anniversary of the events in Stonewall, academic discussions about it, especially those whose stated objective is to think through the intersectional dynamics of its history and aftermath, must be reflexive of how they reproduce-however unintentionally-racial, gender, class, and neo-colonial forms of domination. This conference, like others, should be remembered not only for the ideas its participants discussed but also for the circumstances in which it was created. Indeed, as political scientists, sociologists, theorists and other scholars have amply analyzed (see for example: Amari 2015; Borrillo and Fassin 2001; Bourcier 2006; Crémieux and Tin 2013; Perreau 2018) the politics of research on intersex, queer, transgender, bisexual, lesbian, and gay people in France, as in other countries, is fraught. For example, what is often described as the first major French conference on gay and lesbian studies, which took place at the Centre Pompidou in 1997, is remembered as much for the talks by speakers from Europe and North America as for the strong public criticisms it received both from public officials outraged by unabashed academic discussion of homosexuality and from scholars who saw the conference as consensual and decidedly unradical. The Stonewall conference in Créteil took place in the wake of these earlier events and contributed its own chapter to this ongoing story.

Keeping track of this intellectual history is important because it gives insight into how social structures shape our collective understanding of heterosexism and resistance against it. In particular, we must be attuned to the biases created in the literature that stem from the unequal access of non-white and gender non-conforming people to the places where knowledge production happens. Indeed, much like the story of "gay liberation" itself, the overrepresentation of white cis-gender, middle-class men with institutional power in disciplines studying gender and sexuality means that their perspectives tend to overshadow or even erase those of people from other marginalized groups. This phenomenon distorts the science and perpetuates injustice. The Créteil conference explicitly confronted this issue in several ways.

4 First, in response to public critiques from scholars and activists who pointed out an over-inclusion of people from dominant social groups-such as this author-in the scientific committee tasked with analyzing the paper proposals, the organizers halted the submission process and changed the committee's composition by adding new members from more diverse backgrounds. The criticism and response show that the issue of intersectional exclusion can no longer go unaddressed.

5 Second, the content of the conference shined a bright light on the problematic history of Stonewall as an event and as a politics of memory. It also opened up avenues for thinking about the ways we can undo the injustices produced by the Stonewall Myth by showing how trans and racialized people in particular have always been doing such work without recognition and often in the face of hostility from people within predominantly gay and lesbian spaces. In addition, some of the talks explicitly sought to decenter and question the Americanness of narratives that situate Stonewall as the foundation of a new era of gay rights, with all the "Prides" and symbols it supposedly gave birth to. 


\section{Decentering dominant narratives: the content of the conference}

6 Tying these threads together, the conference opened with talks by Emmanuel Beaubatie (EHESS), Lucie Prauthois (Paris-Dauphine University), and Antoine Servel (Paris-Est Créteil University), each of whom were members of the organizing committee. Their statements laid the groundwork by reminding the audience of the facts of the events that took place around Stonewall and how the story has come to be told in ways that downplay or ignore the key role played by trans, lesbian, queer, and racialized people. They also addressed the criticism of the conference mentioned above as well as the broader national French context in which "gender ideology" has come under increasing attack. Finally, they described how Stonewall mythmaking is a key part of capitalistic and neo-colonial rainbow-washing, in which private enterprise and the state use symbols of "gay pride" as marketing or diplomatic ploys even as they uphold heterosexist institutions and practices.

7 The sociologist Mignon Moore (Barnard College, Columbia University, US) gave the first keynote address, providing details from her research on Black lesbian families in the United States in particular (Moore 2011) and the "cross-cutting" issues (Cohen 1999) of race and sexuality in general. Moore highlighted how processes of racial identity construction on the one hand and sexual identity construction on the other work in different, and sometimes conflicting ways for Black gay, lesbian, bisexual, and trans people, because of the specific histories shaping the meaning and structure of these racial and sexual categories.

8 The panel, "Questioning the Centrality of Stonewall," took an interdisciplinary look at the politics of memory-making. Estela Diaz (Columbia University, US) drew on interview data with middle-aged Black sexual minority women to investigate how race, gender, and sexuality shaped their participation in an underground economyincluding sex work-sparked by racist and heterosexist practices preventing them from accessing formalized labor. Shifting to the realm of social movements, Charlotte Thomas-Hébert (Paris-1 Panthéon Sorbonne University) described in minute detail the evolution of New York Pride Marches since the first commemoration of the Stonewall riots in 1970, which would famously become an annual event. Thomas-Hébert's talk revealed the conflicts and power struggles between organizations as they disputed over who could legitimately claim to organize these marches, what the marches should aim to accomplish, and what groups should be included or excluded. Robert Baez (University of Florida, US) presented results from research on contemporary organizations aiming to destabilize the institutionalization of Pride in order to make it more explicitly political and accountable to Black and other marginalized queer people. Focusing on France, Quentin Zimmerman (University of Lille 3) brought to light the pressing issue of queer archives and their preservation from distortion and destruction. Combining Spivak's concept of epistemic violence with Derrida's archival violence, Zimmerman showed how Stonewall acts as a commemorative apparatus whose gravitational pull can cause damage to the way queer histories are saved (or not) through archival practices that treat Stonewall as the standard against which all other events should be measured.

9 The first day ended with the projection of the film History Doesn't Have to Repeat Itself by Stéphane Gérard, which primarily features interviews with US leaders of lesbian, 
feminist, gay, trans, and queer organizations devoted to pursuing justice. As a Black Frenchman, Gérard provides an important perspective on the possibility of radical liberation in France and the political and ideological distance across the two countries he moves between.

In different ways, speakers on the second panel, "Representing Stonewall: Celebration, Invisibilization, Normalization, and Homonormativity," asked about how Stonewall has been mediated. Anna Carolin Müller (Kassel University, Germany) analyzed the way Roland Emmerich's film Stonewall, which many film critics, scholars, and activists panned because of its historical inaccuracies, centered on the narrative of a fictive white, cis-gender gay man. In so doing, it reframed the events around the Stonewall Riots for a mainstream audience at the expense of the real stories of the trans women of color, such as Marsha P. Johnson and Sylvia Rivera, whose role is erased in the film. Looking at theatre, Xavier Lemoine (Paris-Est-Marne La Vallée University) presented a short history of gay stagecraft and the way competing forms of performance, some more mainstream and others more anti-conformist, sought to create a form of gay storytelling that was in part inspired by events around the Stonewall riots. Focusing on the 2014 film Pride about gay and lesbian activists supporting striking miners during Margaret Thatcher's wave of privatizations in the UK, Anamarija Horvat (Northumbria University, UK) presented work on the historical realities represented on screen. Drawing on interviews and archives, Horvat showed how issues of gender, both within the Lesbians and Gays Support the Miners organization and among the wives supporting their striking sons and husbands, were downplayed or ignored in the film. Louise Barrière (University of Lorraine) invited the audience to think about how people in Queercore, the underground music scene present in the US and Western Europe since the end of the 1980s, resisted the commercialization of Stonewall. Using their lyrics, fanzines, and shows, these artists and musicians reminded their audiences that Stonewall was a riot.

11 The second keynote address, delivered by historian Marc Stein (San Francisco State University, US), drew on research from his recent book (Stein 2019), which provides rich archival evidence of the coverage of the Stonewall riots from varied sources. By mobilizing these records, Stein showed that the story we associate with those days in the summer of 1969 is far more complicated, contested, and misrepresented than we might think. He asked the audience to consider what led people in the Stonewall Inn to fight back against the police raid that night despite the fact that such state oppression was relatively commonplace. After shedding doubt on competing theories, Stein argued that the uprising came about because angry gay, lesbian, bisexual, and trans patrons were reacting against a sudden uptick in police violence after a period of relative calm that they had grown accustomed to. In other words, the Stonewall riots were the result of specific local circumstances related to police behavior and New York electoral politics that coincided with preexisting gay and lesbian activism that had laid the foundation for such a reaction.

Panel three, "The Circulation of Pride Marches" focused on the way the Stonewall Myth has reverberated in peculiar ways outside of the United States. With a focus on late twentieth-century Western Germany and post-unifiation Germany, Lüder Tietz (Carl von Ossietzky University of Oldenburg, Germany) talked about the transnational diffusion of "Pride" discourse and its contestation in Berlin and other German cities. Tietz presented photographic and ethnographic data on the way performance, 
especially that which mocks heterosexist norms, is central to "Christopher Street Day" celebrations. In these contexts, Stonewall is explicitly mobilized as a reference by participants. Looking at the "Marcha del Orgullo de San Salvador," Thierry Maire (EHESS) drew on survey data to ask participants in the capital of El Salvador if they knew about Stonewall and what it signified to them. Maire mapped their responses onto trends related to organizational efforts to reframe Orgullo away from its perceived commercial organizations. Line Chamberland (University of Québec Montréal, Canada) delved into the legal and political history of late twentieth-century Québec, whose trajectory on gay rights issues contrasts with that of its southern neighbor. She described how outrage and violent policing in late 1970s Montréal at the gay club Le Truxx sparked a reaction that some came to think of as the "Stonewall québécois."

Florent Chossière (Paris-Est-Marne la Vallée University) and Alexandra Novitskaya (Stony Brook University, US) presented their work on the fourth panel, which was entitled "Minorities within LGBTQ spaces: creativity, agency, and resistance." Chossière drew on his research with people seeking asylum in France because of their sexual orientation and gender identity. His analysis focused in particular on how these people engage with traditionally commercial spaces, such as bars, clubs, bathhouses, and other places for socialization to try to find solidarity and a sense of belonging despite encountering racism and other forms of discrimination. Novitskaya examined the experiences of Russian-speaking lesbian, gay, bisexual, transgender, and queer migrants in New York City as they moved between ethnic enclaves in Brooklyn, conceived of as relatively unwelcoming to their queer identities, and recognizably "gay neighborhoods" in other parts of the city.

The final panel broadened the scope out to "The Globalization of LGBTQ activism." In an intentionally provocative manner, Dennis Altman (La Trobe University, Australia) asked why it is that the history of gay and lesbian liberation in the United States continues to exert such an impact on global conversations about sexual democracy even though the rights of queer people are far less respected there than in many other countries. Altman argued that scholarship must decenter Western events if it is to meaningfully engage with the advances and retreats of legal and social gains for queer people. Mathias Quéré (University of Toulouse) brought our attention back to France, where he argued that many people are intimately familiar with the story of Stonewall but are ignorant of the rich history of French people who fought against heterosexist social norms. His presentation excavated the record of infighting, alliances, dealings, and spinoffs between and among the many varieties of homosexual organizations in the 1970s, such as the GLH (Groupe de libération homosexuelle), the FHAR (Front homosexuel d'action révolutionnaire), and CUARH (Comité d'urgence anti-répression homosexuelle). Alexander Kondakov (University of Helsinki) presented an analysis of homosexuality in the press aimed at the youth of the Soviet Union over a long portion of the twentieth century. This content analysis shows three main stages in the way this literature talked about homosexuality, moving between more open periods to more repressive ones depending on the political context and the reaction of the Soviet Union to geopolitical events and transnational queer organizing. Kevin Niklas Breu (Bremen University, Germany) compared movements fighting against AIDS, such as Act-Up, in France, Germany, and the United States. He found that collective action frames-how activists turn political demands into behavioral patterns in their everyday lives-in AIDS activism depended on the national contexts. Each of the countries Breu analyzed 
had political opportunity structures that varied systematically in terms of the conception of collective identity, making more or less difficult for activists to stake their claims as a group fighting against AIDS.

The conference ended with a roundtable discussion between Line chamberland, Dennis Altman, and Karine Espineira (LEGS research group, Paris 8 Vincennes SaintDenis University). The organizers tasked them with the unenviable job of analyzing the proceedings of the conference in situ. Each speaker has a long history of breaching the divide between activism and academics in their respective fields and countries. As such, their voices were especially important for providing perspective on the work accomplished and unaccomplished over the course of the three days in Créteil. Chamberland regretted that more Latin American voices were not present to provide their perspectives to the conversation. She then talked to the audience about her experiences navigating between feminist and lesbian spaces in the Québec activist and academic scenes where rivalries and tensions are not uncommon. Altman encouraged the audience to consider Gramsci's concept of organic intellectuals in order to counteract the idea that people cannot simultaneously be involved in social movement organizing and scholarship. To support this idea, he described his experiences bridging this gap in the 1980s. In her particularly inspiring speech, Karine Espineira reminded us that gender nonconforming people, trans people, and other sexual and gender minorities are often the targets of heterosexist and nationalist regimes. Drawing on several examples, including Chile, she laid out a theoretical framework for understanding how the state mobilizes heterosexist violence in times of crisis in order to maintain authoritarian control.

Those in attendance left the conference having encountered ideas that should have dislodged any certainties they might have had previously about the 1969 uprising in New York and its outsized impact on global discourse. Many people have a personal, sometimes intimate, sense of what Stonewall means to them, even if they have little sense of the histories of queer organizing in their own locales. What indeed is Stonewall?

Activists and journalists (and later scholars) started debating this question even as the riots in Greenwich Village were still taking place. One lesson we can take away from this event is that our interpretations of Stonewall are much more consequential than people may realize. The legacy of the Créteil conference on this question will be determined by the people who write about and discuss it in the years to come.

\section{BIBLIOGRAPHY}

AMARI, Salima. “Certaines lesbiennes demeurent des femmes." Nouvelles Questions Féministes, vol. 34, no. 1, 2015, p. 70-83.

ARMSTRONG, Elizabeth A., and Suzanna M. Crage. "Movements and Memory: The Making of the Stonewall Myth.” American Sociological Review, vol. 71, no. 5, 2006, p. 724-751. 
BORRILLO, Daniel, and Éric FASSIN, eds. Au-delà du Pacs : L'Expertise familiale à l'épreuve de l'homosexualité. Paris: Presses Universitaires de France, 2001.

BOURCIER, Marie-Hélène. Queer Zones : Politique des identités sexuelles et des savoirs. Paris: Amsterdam, 2006.

COHEN, Cathy J. The Boundaries of Blackness: AIDS and the Breakdown of Black Politics. Chicago, IL: University of Chicago Press, 1999.

CRÉMIEUX, Anne, and Louis-Georges TIN. "Penser ensemble le racisme et l'homophobie." Africultures, no. 96, 2013, p. 13-21.

MOORE, Mignon R. Invisible Families: Gay Identities, Relationships, and Motherhood Among Black Women. Los Angeles, CA: University of California Press, 2011.

PERREAU, Bruno. Qui a peur de la théorie queer ? Paris: Presses de Sciences Po, 2018.

STEIN, Marc. The Stonewall Riots: A Documentary History. New York: New York University Press, 2019.

INDEX

Subjects: Actualité de la recherche

\section{AUTHOR}

\section{MICHAEL STAMBOLIS-RUHSTORFER}

Université Bordeaux Montaigne 